\title{
Bioremediation of Trichloroethylene and cis-1,2-Dichloroethylene-Contaminated Groundwater by Methane-Utilizing Bacteria
}

\author{
Kumi ARAI ${ }^{1,2)}$, Toshiaki TSUBONE ${ }^{1)}$, Tatsuo TAKECHI ${ }^{1)}$ and Takeshi INOUE ${ }^{2}$ \\ ${ }^{1}$ Engineering Research Center, NKK Corporation, 1-1 Minamiwatarida, Kawasaki-ku, Kawasaki, Kanagawa 210-0855, and ${ }^{2}$ The \\ United Graduated School of Veterinary Science, Yamaguchi University, 1677-1 Yoshida, Yamaguchi 753-8515, Japan \\ (Received 25 November 1998/Accepted 25 February 1999)
}

ABSTRACT. Experimental studies on the bioremediation of groundwater contaminated with low concentration trichloroethylene (TCE) and cis1,2-dichloroethylene (DCE) were performed with two sets of bioreactors. Reactors No. 1 and No. 2 were operated without and with methane supplement, respectively. No inoculum was used. The concentrations of TCE and DCE in the effluent and the off gas from reactor No. 2 were much lower than those from reactor No. 1. When air and an $\mathrm{H}_{2} \mathrm{O}_{2}$ solution were supplied to reactor No. 2, concentrations of TCE and DCE in the effluent and the off gas were lower than the lowest detectable limit. The population of methaneutilizing bacteria in reactor No. 2 was 1,000 times higher than that in groundwater or in the effluent from reactor No. 1. These methaneutilizing bacteria were apparently attributable to the treatment of TCE.-KEY wORDS: bioreactor, methane-utilizing bacteria, trichloroethylene.

J. Vet. Med. Sci. 61(7): 861-863, 1999

Chlorinated short-chain aliphatic compounds such as trichloroethylene (TCE) and cis1,2-dichloroethylene (DCE) are major contaminants of groundwater. Because of the carcinogenic effect and the toxicity to the nerve system of these compounds [15, 21, 22], U.S. Environmental Protection Agency (EPA) revised the maximum permissible concentrations in water to be close to the lowest analytical limit [10]. As for influences of trichloroethylene to livestock, the studies are advanced especially those on chickens. Trichloroethylene induced damage to the immune function, egg quality, reproductive performance, nutritional performance and embryo development in broiler chickens $[4,9,23,24]$.

These compounds are water soluble and cannot be removed from groundwater by conventional water-treatment techniques. Gas-stripping, which is the most general method now, has the possibility to cause atmosphere pollution. Bioremediation is one of the most promising technologies for the treatment of these compounds, since it has the possibility to transform toxic compounds to such non toxic ones as carbon dioxide, water, inorganic acids and so on. Methane-utilizing bacteria are reported to cometabolize TCE and DCE with methane-mono-oxygenase, which normally works for oxidation of methane to methanol $[5,7,12,14$, 27]. The complete mineralization of TCE to $\mathrm{CO}_{2}$ appears to be carried out most efficiency by the combined action of methanotrophic and heterotrophic microbial populations [20]. The potential for in situ bioremediation of chlorinated ethenes was demonstrated with a pilot-scale field study [17]. The cometabolic biotransformation of chlorinated ethenes resulted from the biostimulation of indigenous methanotrophic bacteria through the addition of methane as a growth substrate and oxygen as an electron acceptor. The objective of this study was to evaluate the indigenous bacteria in TCE-contaminated groundwater that are capable of growing and showing the bioremediation ability of in two bioreactors. Reactor No. 1 was supplied with oxygen and reactor No. 2 was supplied with oxygen and methane.
Two bioreactors were packed with $1,000 \mathrm{ml}$ (an effective volume of $500 \mathrm{ml}$ ) cylindrical $\left(4 \mathrm{~mm}^{\mathrm{OD}}, 3 \mathrm{~mm}^{\mathrm{ID}}, 5 \mathrm{~mm}^{\mathrm{L}}\right)$ carriers made of polypropylene [18]. No inoculum was used. These reactors were operated in a single-pass mode with a hydraulic retention time of $8 \mathrm{hr}$. The influent groundwater flow rate was $1 \mathrm{ml} / \mathrm{min}$, the air flow rate of reactor No. $15 \mathrm{ml} / \mathrm{min}$, the air flow rate of reactor No. 24 $\mathrm{m} l / \mathrm{min}$ and the methane flow rate of reactor No. $21 \mathrm{ml}$ min. The concentration of $\mathrm{H}_{2} \mathrm{O}_{2}$ supplied was $0.3 \%$ and a $0.3 \% \mathrm{H}_{2} \mathrm{O}_{2}$ solution flow rate was $5 \mathrm{ml} / \mathrm{hr}$. An experiment which used $\mathrm{H}_{2} \mathrm{O}_{2}$ as the oxygen source of supply of the bioreactor was reported by Gerhard et al. [8]. The concentration of $\mathrm{H}_{2} \mathrm{O}_{2}$ was so set as to make 13 ppm oxygen in the reactors based on the field experiment made by Semprini et al. [17]. The number of heterotrophic bacteria was calculated by counting colonies, which appeared on standard agar plates (Eiken Co., Tokyo, Japan) incubated at $25^{\circ} \mathrm{C}$ for 7 days. The methanotrophic bacteria were counted by the most probable number (MPN) method after 8 weeks of incubation in nitrate mineral salts (NMS) medium [26] under an atmosphere of methane-air (1:4) in a desiccator at $30^{\circ} \mathrm{C}$. Samples for determination of TCE and DCE concentrations in liquids were prepared by the head-space method [1] and gas samples were analyzed with a gas chromatograph (Type GC-311, HNU Co., U.S.A.). Dissolved oxygen (DO) was analyzed with a DO meter. Groundwater contaminated with about $0.6 \mathrm{ppm}$ of TCE and $0.2 \mathrm{ppm}$ of DCE was used as influent. There were $1 \times 10^{3}$ $\mathrm{MPN} / \mathrm{m} l$ of methane-utilizing bacteria in this groundwater.

At first, oxygen was supplied to reactors by aeration. Methane-utilizing bacterial flocculation, a substantial growth of salmon-pink-colored biomass, was seen in the whole reactor No. 2 in two weeks after the beginning the experiment, and then, decrease in TCE became apparent and DO in effluent dropped from $7.5 \mathrm{ppm}$ to $1.0 \mathrm{ppm}$ in reactor No. 2. Finally, more than $90 \%$ of TCE and more than $70 \%$ of DCE were removed from reactor No. 2 in 3 weeks. However, in reactor No. 1, no change occurred 
during this period. In reactor No. 1, the removal rate of TCE and DCE reached $60 \%-70 \%$ in 3 months after the start of the experiment. A mass balance for TCE and DCE was calculated after the TCE and DCE concentrations of the effluent reached constant state. The data are presented in Table 1. The TCE concentration of the effluent from reactor No. 2 was undetectable, so it was lower than $0.03 \mathrm{ppm}$, the maximum permissible concentration in the environmental water in Japan (referred to as the maximum permissible concentration). On the other hand, in reactor No. 1, the TCE concentration in the effluent was $0.05 \mathrm{ppm}$, above the maximum permissible concentration. DCE concentrations in the effluents from both reactors were lower than 0.04 ppm, the maximum permissible concentration. Volatilized TCE and DCE from reactor No. 2 were also lower than those from reactor No. 1. The concentrations of DO of effluent from reactor No. 1 were 7.3-7.4 ppm, and those from reactor No. $20.8-1.8 \mathrm{ppm}$.

We examined for the effects of addition of a $0.3 \% \mathrm{H}_{2} \mathrm{O}_{2}$ solution to improve the supply performance of the oxygen which is an important factor. We compared two cases ; supplying only a $0.3 \% \mathrm{H}_{2} \mathrm{O}_{2}$ solution and supplying a $0.3 \%$ $\mathrm{H}_{2} \mathrm{O}_{2}$ solution with air. The results are shown in Table 2 . In effluent from reactor No. 1, DO didn't change, being 7.3-7.4 ppm. TCE concentrations in the effluent from reactor No. 1 were above the maximum permissible concentration in both cases. Especially, when oxygen was supplied with $\mathrm{H}_{2} \mathrm{O}_{2}$ without air, TCE concentrations of the effluent from reactor No. 1 increased, although volatilized TCE decreased to $0 \%$. This result showed that one of mechanisms for removal of TCE in reactor No. 1 was a gas stripping effect. In contrast, in reactor No. 2, concentrations of TCE in the effluent and the off gas were lower than the lowest detectable limits in both cases. DCE concentrations in the effluent from reactor No. 1 were lower than the maximum permissible concentration. In reactor No. 2 , the DCE concentration in the effluent increased to $0.04 \mathrm{ppm}$ when only a $0.3 \% \mathrm{H}_{2} \mathrm{O}_{2}$ solution was supplied. In this case, the bottom and the edge of reactor No. 2 became black and the effluent gave off a smell of $\mathrm{H}_{2} \mathrm{~S}$ and DO in effluent of reactor No. 2 was approximately $1.3 \mathrm{ppm}$. In this case, it seemed that anaerobic microbiological reaction was caused by lack of aeration mixing in reactor No. 2. Biodegradation of chlorinated toxic compounds such as PCE and TCE under anaerobic conditions, being natural in groundwater, has been reported [25]. It has also been reported that one mole of TCE is transformed to one mole of DCE by an anaerobic reaction [16]. Therefore, when only a $0.3 \% \mathrm{H}_{2} \mathrm{O}_{2}$ solution is supplied in reactor No. 2, it seemed that some of TCE was transformed to DCE.

From operation data, the most preferable operational condition to treat TCE and DCE was seemed to be that adding $\mathrm{H}_{2} \mathrm{O}_{2}$ with air in reactor No. 2, since TCE and DCE in the effluent or the off gas were not detected. DO in effluent from reactor No. 2 increased to $2.7 \mathrm{ppm}$. From these results, it is supposed that efficiently supplying oxygen into reactor improves the bioremediation activity. In reactor No. 1, the removal effect was seen, however, the maximum permissible concentration was not clear. Further studies are needed to investigate more efficient operation condition.

The number of methane-utilizing bacteria and heterotrophic bacteria in the feedstock groundwater and in the effluent of reactor No. 1 and No. 2 are presented in Table 3. The number of methane-utilizing bacteria in the effluent of reactor No. 2 was 1,000 times higher than that in the feedstock groundwater and that of the effluent from

Table 1. Fate of compounds applied to reactors

\begin{tabular}{|c|c|c|c|c|c|c|c|c|c|}
\hline Compound & $\begin{array}{l}\text { Concen- } \\
\text { tration } \\
\text { applied }\end{array}$ & $\begin{array}{l}\text { Concen- } \\
\text { tration in } \\
\text { effluent }\end{array}$ & Effluent & $\begin{array}{l}\text { Vola- } \\
\text { tilized }\end{array}$ & $\begin{array}{c}\text { Degraded } \\
\text { or not ac- } \\
\text { counted }\end{array}$ & $\begin{array}{l}\text { Concen- } \\
\text { tration in } \\
\text { effluent }\end{array}$ & Effluent & $\begin{array}{l}\text { Vola- } \\
\text { tilized }\end{array}$ & $\begin{array}{c}\text { Degraded } \\
\text { or not ac- } \\
\text { counted }\end{array}$ \\
\hline & & \multicolumn{3}{|c|}{ Reactor No. 1} & \multicolumn{5}{|c|}{ Reactor No. 2} \\
\hline & ppm & ppm & \multicolumn{3}{|c|}{$\%$ of material applied } & ppm & \multicolumn{3}{|c|}{$\%$ of material applied } \\
\hline TCE & 0.51 & 0.05 & 10 & 13 & 77 & tr.* & 0 & 2 & 98 \\
\hline DCE & 1.14 & 0.03 & 21 & 18 & 61 & 0.02 & 14 & 11 & 75 \\
\hline
\end{tabular}

Table 2. Fate of compounds applied to reactors by different oxygen supply methods

\begin{tabular}{|c|c|c|c|c|c|c|c|c|c|c|}
\hline Compound & $\begin{array}{l}\text { Oxygen } \\
\text { suppling } \\
\text { method }\end{array}$ & $\begin{array}{l}\text { Concen- } \\
\text { tration } \\
\text { applied }\end{array}$ & $\begin{array}{l}\text { Concern- } \\
\text { tration in } \\
\text { efflent }\end{array}$ & Effluent & $\begin{array}{l}\text { Vola- } \\
\text { tilized }\end{array}$ & $\begin{array}{c}\text { Degraded } \\
\text { or not ac- } \\
\text { counted }\end{array}$ & $\begin{array}{l}\text { Concen- } \\
\text { tration in } \\
\text { effluent }\end{array}$ & Effluent & $\begin{array}{l}\text { Vola- } \\
\text { tilized }\end{array}$ & $\begin{array}{l}\text { Degraded } \\
\text { or not ac- } \\
\text { counted }\end{array}$ \\
\hline & & & \multicolumn{3}{|c|}{ Reactor No. 1} & \multicolumn{5}{|c|}{ Reactor No. 2} \\
\hline & & ppm & ppm & $\%$ of mat & erial app & & ppm & $\%$ of mater & rial appl & lied \\
\hline \multirow[t]{2}{*}{ TCE } & $\mathrm{H}_{2} \mathrm{O}_{2}$ & 0.58 & 0.13 & 22 & 0 & 78 & tr.* & 0 & 0 & 100 \\
\hline & air $+\mathrm{H}_{2} \mathrm{O}_{2}$ & 0.58 & 0.09 & 16 & 4 & 80 & tr. & 0 & 0 & 100 \\
\hline \multirow[t]{2}{*}{ DCE } & $\mathrm{H}_{2} \mathrm{O}_{2}$ & 0.06 & 0.02 & 33 & 0 & 67 & 0.04 & 67 & 7 & 26 \\
\hline & air $+\mathrm{H}_{2} \mathrm{O}_{2}$ & 0.18 & 0.02 & 11 & 12 & 77 & tr. & 0 & 0 & 100 \\
\hline
\end{tabular}


Table 3. Numbers of bacteria

\begin{tabular}{lccc}
\hline & $\begin{array}{c}\text { Ground water } \\
(/ \mathrm{m} l)\end{array}$ & $\begin{array}{c}\text { Effluent from reactor No. 1 } \\
(/ \mathrm{m} l)\end{array}$ & $\begin{array}{c}\text { Effluent from reactor No. 2 } \\
(/ \mathrm{m} l)\end{array}$ \\
\hline Heterotrophic bacteria $(\mathrm{CFU} / \mathrm{m} l)$ & $4.3 \times 10^{3}$ & $4.9 \times 10^{4}$ & $2.2 \times 10^{6}$ \\
Methanotrophic bacteria $(\mathrm{MPN} / \mathrm{m} l)$ & $1.2 \times 10^{3}$ & $1.2 \times 10^{3}$ & $1.2 \times 10^{6}$ \\
\hline
\end{tabular}

reactor No. 1. Heterotrophic bacteria in reactor No. 2 numbered 1,000 times and in reactor No. 110 times higher than in the influent. These results suggest that the performance of TCE and DCE-contaminated groundwater treatment is related with the number of methane-utilizing bacteria and heterotrophic bacteria. The number of the necessary methane-utilizing bacteria and the quantity of methane must be determined. Further, studies are needed to find how long the TCE degradation ability lasts with only the oxygen supply when methane-utilizing bacteria increased.

Methane-utilizing bacteria typically co-exist with heterotrophic bacteria that scavenge the metabolites of the methane-utilizing bacteria. Since methane-utilizing bacteria are very sensitive to a trace of organic metabolites of the methane-utilizing bacteria themselves $[6,11]$. It has also been reported that methane-utilizing bacteria lost the ability of degrading TCE in several days due to the inhibitory effects of the products of TCE degradation [2]. So a dualstep reactor system which involves a TCE degradation step and a methane-utilizing bacteria activity recovery step has been proposed $[13,19]$. In the present study, the TCEremoving efficiency was maintained without the recovery system. Therefore, the TCE degradation activity of methane-utilizing bacteria might have been maintained by the cooperative metabolic interaction with heterotrophic bacteria formed in the reactors. We have reported that a mixture of bacteria, which was separated from reactor No.2 and identified as Methylomonas methanica and Pseudomonas sp., removed TCE by an apparantly cooperative metabolic interaction [3].

Further studies on the methanotrophic and heterotrophic microbial populations in the reactor will be necessary.

ACKNOWLEDGEMENT. This study was conducted under a cooperative research project with Environmental Protection Bureau of Yokohama City. The authors express their sincere thanks to all the related people of the Bureau.

\section{REFERENCES}

1. Akiba Z., Shono A., Atsuta M. and Daigo I. 1992. pp. 22-27. The Proceedings of the Second Symposium on the Geo-Environments.

2. Alvarez-Cohen, L. and Macrty, P. L. 1991. Appl. Environ. Microbiol. 57: 228-235.

3. Arai, K., Tsubone, T., Takechi, T. and Inoue, T. 1999. J. Vet.
Med. Sci. 61: 295-298.

4. Bross, G., Difrancrisco, D. and Desmond, M, E. 1983. Toxicology 28: 283-294.

5. Donna, E. F., Shelia, E. U. and William J. J. 1992. Biotechnol. Bioeng. 40: 1218-1232.

6. Fogel, M. M., Taddeo, A. R. and Fogel, S. 1986. Appl. Environ. Microbiol. 51: 720-724.

7. Fox, B.G., Borneman, J. G., Wackett, L. P. and Lipscomb, J.D. 1990. Biochemistry 29: 6419-6428.

8. Gerhard, S., Markus, T. and Rolf B. 1992. Wat. Res. 26: 273 178.

9. Hong,S. B., Ishikawa, S., Kim, Y. W., Nozaki, Y., Oyuyama, K., Shioda, S., Han, H. S. and Nakai, Y. 1993. Showa Univ. J. Med. Sci. 5: 27-38.

10. Lackey, L. W., Phelips, T. J., Bienknowski, P. R. and White, D. C. 1993. Appl. Biochem. Biotechnol. 39: 701-713.

11. Lidstorm-O'connor, M.E., Fulton, G. L. and Wopt, A. E. 1983. J. Gen. Microbiol. 129: 3139-3148.

12. Little, C. D., Palumbo, A. V., Herbes, S. E., M., Lidstorm, E., Tyndall, R. L. and Gilmer, P.J. 1988. Appl. Environ. Microbiol. 57: 951-956.

13. MacFarland, M. J., Vogel, C.M. and Spain, J.C. 1992. Wat. Res. 26: 259-265.

14. Moore, A. T., Vira, A. and Fogel, S. 1989. Environ. Sci. Technol. 23: 403-406.

15. National Cancer Institute 1976. Carcinogenesis bioassay of trichloroethylene, NCI-CG-TR-2.

16. Ninomiya, K., Sakai, M. and Kashiwagi, N. 1992. J. Soc. Wat. Environ. 15: 822-827.

17. Semprini, L., Hopkins, G. D., Roberts, P. V. and McCarty, P.L. 1992. J. Hazard. Mater. 32: 145-162.

18. Tsubone, T., Ogaki, Y., Yoshy, Y. and Takahashi, M. 1992. Wat. Environ. Res. 64: 885-889.

19. Uchiyama, H., Oguri, K., Nishibayashi, M., Kokufuta, E. and Yagi, O. 1995. J. Ferment. Bioeng. 79: 608-613.

20. Uchiyama, H., Nakajima, T., Yagi, O. and Nakahara T. 1992. Appl. Environ. Microbiol. 58: 3067-3071.

21. US Environ. Protect. Agency 1975. Report on Suspecte Carcinogenicity of trichloroethylene, June, 17.

22. Utsumi, H., Kiyoshige, K., Mitade, C., Han, S. K., Hakoda, M. and Hamada, A 1992. Water Sci. Tech. 26: 247-254.

23. Vodela, J. K., Renden, J. A., Lenz, S. D., Mcelhenney, W. H. and Kemppainen, B. W. 1997. Poult. Sci. 76: 1474-1492.

24. Vodela, J. K., Renden, J. A., Lenz, S. D., Mcelhenney, W. H. and Kemppainen, B. W. 1997. Poult. Sci. 76: 1493-1500.

25. Vogel, R. M. and McCarty, P. L. 1985. Appl. Environ. Microbiol. 49: 1080-1083.

26. Whittenbury, R., Phillips, K. C. and Wilkinson, J. F. 1970. J. Gen. Microbiol. 61: 205-218.

27. Wilson, J. T. and Wilson, B.H. 1985. Appl. Environ. Microbiol. 49: 242-243. 